\title{
Vasyl Avramenko's Creative Heritage in Context Folk Choreography of the XXI Century
}

\author{
Bigus Olga Olegivna \\ Candidate of Art History, Honored Worker of Arts of Ukraine, \\ Associate Professor, Dean of the Faculty of Choreographic Art, \\ Kyiv National University of Culture and Arts, Kyiv, Ukraine
}

\begin{abstract}
The study is devoted to the preservation and reconstruction of the author's choreography at the present stage of development of performing arts. On the example of the creative heritage of the leading Ukrainian choreographer, the founder of the national stage folk dance Vasyl Avramenko, an attempt was made to analyze the peculiarities of modern choreographers' treatment of famous Ukrainian folk stage dances of the first half of the twentieth century.

The study found that: in the process of working on folk-stage dance or dance composition, the author of the choreographic text of which is V. Avramenko, it becomes important to focus on artistic qualities that defined V. Avramenko's productions, in particular, emotional tension and the desire to reflect human characters. the context of the historical period, the choreographic poeticization of the figurative side of national patriotism, the use of dramatization as the dominant means, etc .; appeal to V. Avramenko's choreographic heritage of modern choreographers promotes the expression of ethnic identity; the most expedient strategies for processing folk-stage dance or choreographic composition, the author of the choreographic text of which is V. Avramenko, it is expedient to consider the reproduction of the author's production and adaptation to the level of technical training of dancers.
\end{abstract}

Key words: V. Avramenko, folk-stage dance, folk choreography, choreographer, authentic dance, arrangement.

Актуальність дослідження. Танцювальна культура українського народу вирізняється багатоманіттям художніх особливостей, що проявляються в образності, лексичній манері, стилі виконання відповідно до загальнонаціональної та регіональної специфіки. На сучасному етапі можемо говорити про історично сформовану систему виражальних засобів, що складають мистецтво українського народно-сценічного танцю. Водночас тенденції сценічного мистецтва початку XXI ст. вимагають від хореографічних постановок новаторства сценічних форм, виражальних засобів, актуальних та естетичної спрямованості. У цьому контексті надзвичайно актуалізується проблематика створення хореографічних композицій народно-сценічного танцю на основі авторських текстів.

Багато сюжетних та безсюжетних танців, створених В. Авраменком, в яких відображені національні традиції української народної музичної та танцювальної творчості, складають золотий фонд вітчизняної хореографії та є невід’ємною частиною 
репертуару професійних та аматорських ансамблів танцю. На сучасному етапі розвитку народно-сценічної хореографії багато балетмейстерів звертається до танцювальних композицій, авторство яких належить В. Авраменку з метою створення на їх основі сучасних обробок.

У даній статті творчий спадок В. Авраменка розглядається крізь призму проблематики трансформаційних процесів танцювальної лексики в хореографічних композиціях сучасних українських балетмейстерів, що розглядається нами як одна 3 актуальних проблем народно-сценічної хореографії XXI ст.

Аналіз публікацій. Мистецький доробок видатного вітчизняного хореографа, одного з перших авторів самостійних сценічних постановок народного танцю В. Авраменка протягом багатьох десятиліть стає предметом наукових досліджень не лише українських, а і закордонних теоретиків танцю, культурологів та мистецтвознавців - Ю. Станішевського, Н. Зубаревої, М. Мушинки, О. Костюка, П. Білаша, А. Нагачевського, Г. Лагойдюка, Ф. Погребенника, I. Книш, І. Пігуляка та ін. Серед публікацій останніх років можемо назвати дослідження Л. Косаковської «Мистецька парадигма В. К. Авраменка в контексті розвитку української культури XX століття» [3], статтю Н. Марусик «Василь Авраменко - плюси і мінуси творчої діяльності» [5], публікації К. Островської «Збереження та розвиток національних традицій у хореографічних колективах української діаспори» [7], Л. Турчак «Творчість Василя Авраменка та його внесок в українську та світову культуру» [10] та ін. Проте особливості процесу художньої обробки народно-сценічного танцю або танцювальної композиції, автором хореографічного тексту яких є В. Авраменко на сучасному етапі лишаються практично невисвітленими.

Мета статті - виявити специфіку створення сучасними хореографами обробок авторських танцювальних композицій В. Авраменка та визначити особливості трансформації лексики народно-сценічного танцю в XX ст. і на сучасному етапі.

Виклад основного матеріалу. Важливою умовою розвитку народної хореографії є стабільність танцювального репертуару, що базується на естетиці української народної творчості. Не розрахований на сценічне виконання, автентичний танець, як невід’ємна частина народної календарної та родинно-побутової обрядовості передавався 3 покоління до покоління, накопичуючи та відшліфовуючи гармонію 
виражальних засобів. Найкращі з них склали художню скарбницю народного мистецтва і стали основою народно-сценічної хореографії.

Успіхи «неперевершеного творця нового напрямку в народно хореографічній культурі» [9, с. 80] В. Авраменка в розробці народно-сценічних танців - завдяки органічному поєднанню фольклорних зразків з лексикою класичного танцю майстер посприяв переходу народно-сценічного танцю на новий рівень - багато в чому визначаються серйозним творчим зверненням балетмейстера до глибокого вивчення життя та танцювальної культури українського народу.

Отримавши педагогічну освіту до початку Першої світової війни, а після закінчення - театральну та хореографічну (навчався у Київській драматичній школі імені М. Лисенка; як учень В. Верховинця, допомагав відомому антропологухореографу збирати народні танці українськими селищами), В. Авраменко працював у театрах Й. Стадника (м. Станіслав) та М. Садовського (м. Кам'янець-Подільський) і записував рідкісні стародавні танці зі слів членів акторських труп [5, с. 74]. На думку Л. Косаківської, важливу роль в процесі розробки В. Авраменком народно-сценічного українського танцю відіграла театралізація, на яку майстра надихнули постановки театру М. Садовського [4, с. 249]. У 1919 р. В. Верховинець визначився з назвою загальних кроків та створив метод запису зібраних народних танців, а В. Авраменко, приєднавшись до української армії боровся за національну незалежність України проти Радянського уряду та поляків. У 1921 р., інтернований в табір у Польщі, він заснував школу українського танцю безпосередньо в таборі військовополонених Української Галицької армії у Каліші, а наступні кілька років мандрував іншими таборами для інтернованих та біженців західною Україною (Волинь, Галичина, Холмщина), Чехословаччиною та Німеччиною, навчаючи танцю (ним було відкрито близько 40-ка шкіл українського танцю) і проводячи концертні виступи з власним ансамблем для місцевого населення [9, с. 80]. На думку Б. Зеребецького, ці концерти допомогли В. Авраменку закріпити зв’ язок, який він вбачав між збереженням танцювальних традицій та надією на творчість незалежної української держави, а також відточував власні педагогічні навички та репертуар [13, pp. 26-27]. У пошуках виходу з нестабільної політичної ситуації та впевнений в силі танцю, який надихне на повернення нової, 
сильної України, В. Авраменко поїхав у 1925 р. з Європи до Канади і заснував українську танцювальну школу, пропагуючи національну культуру.

Дж. Станек акцентує на тому, що В. Авраменко вважав своєю місією навчання молоді правильній українській поведінці та українському націоналізму в процесі удосконалення українського танцю як виду мистецтва, закликаючи своїх учнів пишатися власною українською самобутністю та історією. 3 цією метою хореограф активно використовував культурні символи, найсильнішим з яких було українське козацтво. У народно-сценічних композиціях В. Авраменка створив образ козаків як сильних, успішних захисників української нації та ідентичності, які достойні наслідування - у лексиці танцю це отримало виявлення в кроках «присядка» [11, p. 34].

Створення художнього образу досягається засобами хореографічної виразності, вмінням використовувати певні прийоми, що дозволяють передати різноманітні життєві явища, що наповнюють змістом хореографічні твори. У сценічних постановках українського народного танцю, здійснених В. Авраменко, як і в безпосередньо їх виконанні танцюристом, характерною рисою є хореографічна поетизація образного боку націонал-патріотизму - натхненній народним танком він прагнув воскресити в душі українців «запорізький запал», а з ним і вільну соборну Україну. С. Скельчик наголошує на тому, що звернення до народної української культури було типовим для українофілів початку XX ст., оскільки вони прагнули зафіксувати та прославити українську культуру як форму протистояння репресивним режимам, що контролювали українські землі. Українофільські нахили В. Авраменка особливо помітні по його одягу - його завжди бачили в традиційному козацькому одязі [12, p. 37]. Зокрема, навіть назви шкіл танцю, що діяли за ініціативи та під керівництвом В. Авраменка на Волині в 19221923-х рр. засвідчували вплив на національну свідомість українців, наприклад, «Луцька школа українських національних танців артиста-балетмейстера Василя Авраменка». I. Пігуляк, наголошуючи на величезному культурному значенні діяльність майстра в загальноукраїнському контексті та значному впливі на піднесення національної свідомості, посилається на відгуки про виступи В. Авраменка О. Кошиця: «в кожному кроці, в кожній поставі, в кожному русі говорила історична традиція великого вільного народу, такого завзятого в бою, такого ніжного, але бурхливого в коханні, такого веселого й гумористичного в своєму побуті...» [8, с. 21]. Розуміючи, що збереження та 
відродження національних культурних традицій можливе лише на основі взаємозбагачення та звернення до витоків традиційної народної культури, передусім фольклору, В. Авраменко, вносячи в автентичні танці певні зміни в контексті образотворчих форм, посприяв побудові візуального національного образу.

Л. Косаківська, посилаючись на публікацію в журналі «Родовід», подає наступний перелік авторських постановок В. Авраменка, поділяючи їх за сюжетом на постановки героїко-патріотичні (зазвичай історичного змісту), авторські інтерпретації фольклорних першоджерел та танцювальні композиції на актуальну тематику : «Козачок подільський», «Гопак колом з вільним солом», «Гречаники», «Коломийкасіянка», «Великодний хоровод», «Катерина-Херсонка», «Метелиця-в’юча», «Гопак парубоцький», «Танок Гонти», «Журавель весільний», «Чумак», «Запорозький герць», «Аркан коломийський», «Чумачок», «Гонивітер», «Танок Довбуша», «Козак соло», «Вільний гуцул»; балетні картини: «За Україну», «Чумаки», «Січ Отамана Сірка», «Довбушева ніч», «Великдень на Україні», «Русалки» та ін.» [2, с. 824].

На думку В. Дорошенко, хореографічно-педагогічна діяльність В. Авраменка визначається унікальним підходом до створення танцювального образу та інтерпретації фольклорного матеріалу методом «опосередкованого, підкореного ідейно-художньому змісту відповідного сюжету» [1, с. 174].

На початку третього десятиліття XXI ст. інтерес до творчості Василя Авраменка не зменшується ані в академічних колах, ані у вимірі хореографічних практик - сучасні балетмейстери-постановники активно звертаються до спадку майстра в процесі створення власних танцювальних композицій.

Якщо у випадку створення авторської композиції, сценічно високого художнього твору на основі фольклорного матеріалу балетмейстер розвиває та збагачує власною фантазією автентичний танець, здійснюючи обробку враховуючи побудову танцю за законами драматургії, увиразнюючи, урізноманітнюючи та ускладнюючи лексику, зберігаючи іï особливості, манери та характер виконання, збагачуючи фольклорний взірець привнесенням певного сюжету, заснованого на народних звичаях, календарній та родинно-побутовій обрядовості, повір'ях та легендах, історичних образах та ін., то у випадку створення сучасних обробок народно-сценічних танців відомих хореографів 
XX ст. підхід кардинально відрізняється. Існує кілька напрямів обробки оригінального народно-сценічного танцю або авторської хореографічної композиції:

- відтворення авторської постановки з детальним збереженням кількісного та гендерного складу танцюристів, композиційного малюнку, танцювальних комбінацій, музики, реквізиту та костюмів;

- адаптування до рівня технічної підготовки танцюристів: незмінною лишається назва твору, музичний супровід, основні елементи; допускається залучення лексичних новоутворень на основі локальної танцювальної лексики того регіону, фольклорні матеріали населення якого залучив автор першоджерела (наприклад, у випадку творчого спадку В. Авраменка, назвемо народні танці гуцулів (жителів села Микуличин, нині Івано-Франківська область), лексика яких відобразилася у постановках танців «Аркан», «Коломийська дрібонька», «Танець Довбуша, «Вільний гуцул», «Коломийська сіянка»);

- стилізація, в межах якої обробка позиціюється скоріше як створення сучасними балетмейстерами авторської хореографічної композиції або танцю на основі народносценічних творів провідних українських хореографів минулого (для стилізації характерним є трансформація кількох або усіх аспектів першоджерела окрім основного кроку танцю: хореографічної лексики, музичного супроводу, костюмів, складу танцюристів та ін.).

У контексті специфіки теми даної статті, важливим видається аспект авторської позиції В. Авраменка щодо принципів і методів обробки народного танцю.

За свідченням провідного чеського балетмейстера XX ст. В. Лібовицького одного з учнів В. Авраменка в рівненській танцювальній школі (1923р.), майстер активно виступав проти «модернізації та надмірної стилізації народних танців і народного одягу» [6, с. 26], наголошував на важливості відокремлення автентичного танцю від салонного, категорично заперечуючи створення «штучних «коктейлів» об'єднання кроків і фігур із танців різних народів, які так засмітили післявоєнну хореографію» $[6$, с. 26].

Водночас в контексті теми обробки сучасними балетмейстерами народносценічних танців, автором яких є В. Авраменко, постає питання збереження усіх аспектів хореографічного твору засобами нотації. Зафіксовані хореографічні твори 
мають бути, перш за все, адекватні першоджерелу (у випадку, коли нотатором є не автор постановки). Окрім того, досконало володіти системою нотації має не лише нотатор, якій фіксує хореографічний твір, але й балетмейстер, який звертається до авторського першоджерела.

У випадку зі спадком В. Авраменка нотаторами здебільшого є його учні та присутні на концертних виступах теоретики і практики хореографічного мистецтва, відповідно, зважаючи на можливість зміни авторського першоджерела доповненнями інших осіб, складно говорити про адекватність тексту хореографічного твору в постановці В. Авраменка. Перша редакція багатьох народно-сценічних танців В. Авраменка була змінена наступними поколіннями його учнів та виконавців.

У деяких випадках кодування окремих сценічних танцювальних композицій було здійснено адекватно авторському першоджерелу - записано безпосередньо автором. Проте, зважаючи на раритетність записів, отримати вільний доступ до них може далеко не кожен вітчизняний балетмейстер.

Зважаючи на це, а також на рівень розвитку та поширення знімальної апаратури в 1920-1930-ті рр., в процесі аналізу обробок хореографічних творів В. Авраменка сучасними балетмейстерами, доречно говорити скоріше не про хореографічний текст (танцювальні рухи, пози, ракурси, поєднання в певній послідовності всіх танцювальних рухів хореографічного номера), а про специфіку створення майстром художнього образу та характерні ознаки авторського стилю. На основі аналізу архівних джерел, діаспорної літератури та публікацій, здійснених вітчизняними науковцями, можемо виділити наступні якості, якими визначалися постановки В. Авраменка:

- надзвичайне емоційне напруження та прагнення відобразити людські характери в контексті історичного періоду [10, с. 22];

- танцювальна лексика характеризується лаконічністю жестів, ритмічністю та швидкістю виконання рухів, віртуозністю виконання стрибків та кружлянь (наприклад, сольний танець «Чумак»);

- хореографічна поетизація образного боку націонал-патріотизму;

- театралізація як переважаючий засіб (окремі постановки В. Авраменка, наприклад, «Січ отамана Сірка», «Гайдамаки», «Довбушева ніч», «Запорожці пишуть лист до Султана» та ін., на думку дослідників, можна назвати творами театру 
українського танцю, мовою якого став національний танець, що пов'язаний єдиним композиційним рішенням, художнім образом та задумом) [3, с. 7].

Висновки. Дослідження виявило, що звернення до хореографічного спадку В. Авраменка сучасних балетмейстерів сприяє вираженню етнічної ідентичності, а найдоцільнішими стратегіями обробки народно-сценічного танцю або хореографічної композиції, автором хореографічного тексту яких є В. Авраменко, доцільно вважати відтворення авторської постановки та адаптування до рівня технічної підготовки танцюристів.

Значна трансформація українського народно-сценічного танцю, що відбувалася протягом століття, зумовлена специфікою художніх течій, історико-культурної ситуації, мистецьких тенденцій, впливів закордонного досвіду та ін., посприяла розширенню прийомів та методів балетмейстерів-постановників. Проте засади народної хореографії, які репрезентував у власних танцювальних текстах В. Авраменко - правдивість художньої естетики мистецтва танцю, домінування національного елементу та чітке розуміння важливості уникнення шовіністичних впливів, замкненості та критичного наслідування в процесі вільної творчості - лишаються головними.

\section{References}

1. Doroshenko, V. F. (2014). The role of the choreographer P.P. Virsky in the process of the emergence and development of folk stage choreographic art of Ukraine. Bulletin of Slavic Cultures, no. 2 (32), pp. 171-180.

2. Kosakovskaya, L. P. (1999). Vasyl Avramenko and Volyn «Our red family ...». Volyn in the fate of the region and human documents. Lutsk: Ed.-published. department «Tower» VSU. Lesya Ukrainka, Vol. III, pp. 823-834.

3. Kosakovskaya, L. P. (2009). Art paradigm of VK Avramenko in the context of the development of Ukrainian culture of the XX century. Abstract of Ph.D. Kyiv.

4. Kosakovskaya, L. P. (2003). Genre «Ballet picture» choreographed by V. Avramenko. Culture of Ukraine, Issue 12, pp. 248-258.

5. Marusyk, N. I. (2011). Vasyl Avramenko - pros and cons of creative activity. Problems and prospects of development of choreographic art in the context of higher education in Ukraine. Kherson: KSU, 2011. Issue LV111, pp. 73-78.

6. Mushynka, M. (1994). According to the artistic wills of Vasyl Avramenko. Folk art and ethnography, no. 1. p. 26. 
7. Ostrovskaya, K. V. (2018). Preservation and development of national traditions in choreographic groups of the Ukrainian diaspora. Culture of Ukraine, no. 59, pp. 153-162.

8. Pigulyak, I. (1979). Vasyl Avramenko and the revival of the Ukrainian tank. New York.

9. Pogrebennyk F. (1991). Coryphaeus of Ukrainian dance. Folk art and ethnography, no. 2-3, pp. 80-85.

10. Turchak, L. I. (2020). Creativity of Vasyl Avramenko and his contribution to Ukrainian and world culture. Bulletin of the National Academy of Management of Culture and Arts: Science. Magazine, no. 3, pp. 20-27.

11. Staniec, J. (2007). Cossacks and wallflowers: ukrainian stage dance, identity and politics in saskatchewan from the 1920s to the present. A Thesis Submitted to the College of Graduate Studies and Research in Partial Fulfillment of the Requirements for the Degree of Master of Arts in the Department of History University of Saskatchewan Saskatoon. 132 p. URL: https://harvest.usask.ca/bitstream/handle/10388/etd-08262007211713/staniec_j.pdf?isAllowed=y\&sequence $=1$.

12. Yekelchyk, S. (1993). The Body and National Myth: Motifs from the Ukrainian National Revival in the Nineteenth Century. Australian Slavonic and East European Studies, Vol. 7, no. 2, pp. 31-59.

13. Zerebecky, B. A. (1986). Survey of the History of Ukrainian Dance. Saskatoon: Ukrainian Canadian Committee, 1986. pp. 26-27.

\section{Translation of the References to the Author's Language}

\section{Список використаних джерел:}

1. Дорошенко В.Ф. Роль хореографа-постановщика П.П. Вирского в процессе возникновения и развития народно-сценического хореографического искусства Украины. Вестник славянских культур. 2014. № 2 (32). С. 171-180.

2. Косаковська Л. П. Василь Авраменко і Волинь «Роде наш красний...». Волинь у долях краян і людських документах. Луцьк : Ред.-видав. відділ «Вежа» ВДУ ім. Лесі Українки, 1999. Т. III. С. 823-834.

3. Косаковська Л. П. Мистецька парадигма В. К. Авраменка в контексті розвитку української культури XX століття: автореф. дис. на здобуття канд. мистецтвознавства: спец. 26.00.01. Київ, 2009. 16 с.

4. Косаковська Л.П. Жанр «Балетної картини» у хореографії В. Авраменка. Культура України. 2003. Вип.12. С. 248-258.

5. Марусик Н. І. Василь Авраменко - плюси і мінуси творчої діяльності Проблеми та перспективи розвитку хореографічного мистецтва в контексті вищої освіти в Україні. Херсон: ХДУ, 2011. Вип. LV111, Ч. 2. С. 73-78. 
6. Мушинка М. За мистецькими заповітами Василя Авраменка. Народна творчість та етнографія. 1994. № 1. С. 26.

7. Островська К. В. Збереження та розвиток національних традицій у хореографічних колективах української діаспори. Культура України. 2018. № 59. С. 153-162.

8. Пігуляк І. Василь Авраменко і відродження українського танку. Нью-Йорк, 1979. $68 \mathrm{c}$.

9. Погребенник Ф. Корифей українського танцю. Народна творчість та етнографія. 1991. № 2-3. С. 80-85.

10. Турчак Л. І. Творчість Василя Авраменка та його внесок в українську та світову культуру. Вісник Національної академії керівних кадрів культури і мистецтв : наук. журнал. 2020. № 3. С. 20-27.

11. Staniec J. Cossacks and wallflowers: ukrainian stage dance, identity and politics in saskatchewan from the 1920s to the present. A Thesis Submitted to the College of Graduate Studies and Research in Partial Fulfillment of the Requirements for the Degree of Master of Arts in the Department of History University of Saskatchewan Saskatoon. 2007. 132 p.

URL :https://harvest.usask.ca/bitstream/handle/10388/etd-08262007211713/staniec_j.pdf?isAllowed=y\&sequence $=1$.

12. Yekelchyk S. The Body and National Myth: Motifs from the Ukrainian National Revival in the Nineteenth Century. Australian Slavonic and East European Studies. 1993. Vol. 7. no. 2. pp. 31-59.

13. Zerebecky B. A Survey of the History of Ukrainian Dance. Saskatoon: Ukrainian Canadian Committee, 1986. pp. 26-27. 